\title{
The Value of the Endorphin in the First Inhalation the Fruit
}

\section{Shaposhnikov Veniamin Ivanovich*}

Professor of surgical diseases, Russia

*Corresponding author: Shaposhnikov Veniamin Ivanovich, Professor of surgical diseases, Vice Rector, Russia

\begin{tabular}{|c|}
\hline ARTICLE INFO \\
\hline Received: 纽 June 10, 2019 \\
\hline Published: 幽 June 17, 2019 \\
\hline $\begin{array}{l}\text { Citation: Shaposhnikov VI. The Value } \\
\text { of the Endorphin in the First Inhala- } \\
\text { tion the Fruit. Biomed J Sci \& Tech Res } \\
\text { 18(5)-2019. BJSTR. MS.ID.003220. }\end{array}$ \\
\hline
\end{tabular}

Keywords: Depression; Respiratory center, Endorphins, Active breathing

\begin{abstract}
The author assumes that normal healthy fetus that resides in the uterine cavity and surrounded by the waters of the okoloplodnymi, not breathing because his breathing Center depressed endogenous morfinopodobnymi substances which are called endorphins. This way is carried out embryo survival in liquid Wednesday provided gas exchange between him and the mother through the placenta. But as soon as the changes Wednesday to its Habitat, there comes the birth of child, then there is a sharp increase in negative stimuli on his body, and it is accompanied by rapid high consumption "hormones of happiness". Deficit occurs and immediately starts the functional activity of the respiratory Centre. If this does not happen, then unaided comes fetal death. The author bases his opinion on a few clinical observations, when after a serious abdominal operation to eliminate pain, patients assigned morphine, which is analogous to the endorphin, and was immediately stops breathing, but with persistence consciousness. Only translated to managed hardware breath has saved patients. Such breath they have lasted till 5 days. These observations have allowed the author to recommend equipping the wards of respiratory equipment, resorting to it out of necessity, if the fetus is depression of the respiratory Centre.
\end{abstract}

\section{The purpose of the study}

Determine the value of the endorphin in the physiological mechanism of the first breath of a newborn.

\section{Introduction}

On the basis of the modern understanding of the anatomicalphysiological processes underlying breathing at the time of birth the fetus his lungs are in spavshemsja condition, and larynx, trachea, bronchi and acini, filled with fluid, which allocates epithelium the respiratory tract. The respiratory center is in an inactive state called. It is localized in the area of the bottom IV heart brain and consists of three parts: a woman (develops and supports alternation of inhalation and exhalation), apnojeticheskoj (one long con inspiratornyj spasm), pnevmotaksicheskoj (zjashhee Tormo has an impact on apnojeticheskuju part). At term, at the time of birth have already formed reflex self-regulation breathing due to pulmonary mechanoreceptors. Depending on the location and nature of sensitivity there are three types:
a) Stretching,
b) Irritantnye,

\section{c) Jukstapapilljarnye}

The first are predominantly in the tracheal and bronchial smooth muscle. They are excited when you stretch them to the walls and provide a change of phases of respiration. Irritantnye are located in the mucous epithelium of the trachea and bronchi. They react to irritants and dust particles, performing the protective function of the organism. Jukstapapilljarnye receptors are found in the interstitial tissue of the alveoli and bronchi. They are instituted when the pressure increases in the small circle of blood circulation, as well as at increasing the volume of interstitial fluid [1-3].

Thus, the body of the fetus is prepared for an independent life and waiting for her to start, but it does commit the first breath, and the mother seeks to achieve that goal. With the passage of the fetus on her descent channel occurs and agility his chest compression. This is accomplished by expiration fluid from his Airways, which has a low viscosity and therefore rapidly absorbed immediately 
after his birth. This process has been given a lead role in initiating respiratory Centre and newborn implement first breath [4-7]. Occurrence of air into his airway is facilitated as well and the reduction of the diaphragm is accompanied by the development of the fetus have the negative intrathoracic pressure that promotes the flow of air. Surface on the traction in the alveoli is overcome due to the impact of surfactant. As a result of these processes light and straightened, pulmonary fluid rapidly absorbed lymph and blood vessels. Complete cessation of transplacentarnogo blood circulation going to reduce oxygen partial pressure and higher carbon dioxide NIJ.

Immediately arises the impulse from the receptors of the aorta and carotid arteries to the respiratory center. Irritation occurs and the cutaneous receptors of the fetus, because at this time changed dramatically Wednesday its Habitat-the transition from the intrauterine existence to stay in atmospheric Wednesday. This is accompanied by additional stimulation of the respiratory Centre. After the first inhalation, all subsequent regulation of respiration is carried out by the Centre with the participation of Central and peripheral chemo receptors, and Central are major, because they support on stojanstvo $\mathrm{H}+$ in the spinal liquid, with $\mathrm{CO}^{2}$ free coal provides diffundi through the blood-brain barrier. Increase $\mathrm{H}+$ concentration in the spinal fluid stimulates ventilation lungs. Peripheral chemo receptors are sensitive to changes compared to the content of oxygen and carbon dioxide in arterial blood. They are already functionally AK population to the birth of the child. The first breaths cause reflex Herring-Breuer, which manifests itself precisely when you stretch. Impulses of the afferent fibers of the vagus nerves to the respiratory center and arrive in $\beta$-respiratory neurons, which in turn inhibit c-respiratory. Breath stops and starts an exhalation. Data reflexes provide normal frequency and depth of breathing, as well as warn hyperextension lung tissue. A certain value in the reflex regulation of breath are proprioreceptory of the respiratory muscles-impulses from them comes to the respective motonejronam of the respiratory muscles, that regulates the force their reductions, if there is any resistance to breathing. Pnevmotaksicheskoj of the respiratory Centre matures only for the first year of the child's life. This can be explained by the concern expressed by aritmichnost breathing, as well as apnea, which are the most frequent and prolonged in preterm infants at the same time, the lower its body weight, the more often and longer observed apnea. This is illustrated by the lack of maturity of the pnevmotaksicheskoj part of the respiratory Centre. But even more important in the prediction of survival of premature babies is growing rapidly increasing breathing in the first few minutes of life a newborn.

This testimony is insufficient development apnojeticheskoj also part of the respiratory Centre. Found that while still in the mother's body, the embryo as actively trains their respiratory muscles is periodically reduces the diaphragm and other respiratory muscles, mimicking the inhale and exhale. However, okoloplodnaja liquid in the lungs does not arrive, because his voice crack is plugged in firmly state [8-10]. After birth, the newborn oxygen intake and its concentration in the blood is gradually reduced, but $\mathrm{CO}^{2}$ increases. These changes are registered hemoreceptorami of the respiratory Centre, prompting him to activism. It sends impulses to the breathing muscles, and occurs the first breath. Voice crack expands and air rushes into the lower respiratory tract, and then in the alveoli, smoothed out there. First exhalation accompanied by characteristic cry of the newborn. On the exhale alveoli stick together no longer because this prevents surfak Thant. Number of surfactants in preterm infants is not sufficient for proper ventilation.

Therefore, after the birth, there are often various respiratory disorders $[3,9,10]$. Thus, to initiate breathing Centre are participating, as well as the reflex humoral factors, but the mechanism first breaths of the embryo is not fully revealed, and without this process, his life will not take place. For example, what mechanism first breaths in the fetus, if it was removed from the uterus through the abdominal wall (i.e. it does not pass through the birth canal), as well as premature and an embryo, if he had no peremezhajushhego of constriction of the chest. Hence, there is another factor that plays a more important role in inhibiting the respiratory Centre of the embryo and in the implementation of the first breaths while reducing its impact on the Centre. In the inner fetal Wednesday has such substance is endorphins. It is now established that the pituitary gland produces beta-lipotrofin from which neurons in the brain synthesize opiatopodobnoe substance called endorphins [6]. This substance decreases pain and affect the emotional state of a person.

Increased or slowing down this "joy" hormone regulates the hippocampus. It also carries out its functional activity creates emotional comfort to the feeling of happiness and delight. Endorphins begin back in the mother's body, and he runs the stirrings, embryo mechanism motion Analyzer. There is no doubt that the true factor in fetal blockade respiratory Centre is the substance. After all, external analogue available Wednesday endorphin is morphine. Their effect on the human body is well known and it coincides with the above properties of endorphin. There is evidence of inhibition of morphine respiratory Centre, up to a full stop. However, in the medical literature of its analogueendorphins in the mechanism of the first breaths of the fetus is not mentioned. This prompted us to take a fresh look at the mechanism of the first breath of a newborn. It is possible that endorphin is the main physiological factor in the anatomical mechanism first inhaling not only in mammals, but creatures born from eggs (birds, reptiles, etc.). This hypothesis is not only informative, but also of practical interest, because sometimes there is outwardly healthy mjortvorozhdenie the fetus, but without raspravlennyh the lungs, and remains unclear the cause of this deadly disease. And maybe this death to blame the high concentration of endorphin in neurons of the respiratory Centre, which during childbirth has not decreased and did not allow the embryo to make the first breath? If 
this version is correct, then you need to develop a system of datasaving activities.

\section{Material and Methods}

In clinical practice, we have repeatedly encountered torpidnym action of opiates (morphine) on the respiratory center patients. The latest incident took place about 5 years ago. 78 years after a patient at acute cholecystitis, the insistent request of the daughters (for pain relief) young surgeon was appointed morphine at a dose of 1 $\mathrm{ml}$, and immediately stop breathing occurred (without oppression of consciousness). To save the patient needed a managed hardware breath.

\section{The Result of the}

Hardware breathing patient lasted 5 days. Consciousness was retained. During this time, several times tried to restore independent breathing, but this could not be done. Did not help and respiratory analeptic. On the fifth day (the next disconnection apparatus) convulsive breaths come to fruition. Function of the respiratory Centre, kakonec-what is recovered. This physiological process patient was identical to the mechanism of the first breath of a newborn. This idea has led to the involvement and endorphin to the anatomical-physiological mechanism of the first breath of a newborn fetus.

\section{Discussion}

When analyzing the clinical symptoms described observations and taking into account the data of the literature on jendorfinu and opiates, it can be assumed that the patient initially occurred summation steps substances oppressive breathing Center, and he blocked and then recovered, but only after lowering the concentrations of these substances in its neurons and across internal Wednesday. The same thing happens in the embryo, which is located in the cavity of the uterus. His breathing Center blocks the endorphins. All other factors become apparent only after his birth. Endorphins, which in the blood in the embryo has a constant and adequate concentration, at the time of birth is dramatically reduced and he screams not because it hurts, and it requires that drug, i.e. endorphin. The result is the first breath and easy straightened.
Lowering the same endorphin comes from changing Habitat and occurrence of fetal Wednesday mass irritants. Yell all the children, so they are all in the mother's body are influenced by the "hormone of joy". Its concentration varies, which affects the behavior of a newborn fetus. If a child was found "coveted" it calm, and if not, vice versa, that is, it captures the mood of the parents in the real appearance of themselves in their life, it wants to save and develop endorphin intensifies. One has to remember, if the embryo was under the influence of opiatopodobnogo substances in the future, living in atmospheric Wednesday, he can easily "remember" this euphoria from contact with morphine, heroin and other drugs. Parents must be informed in this regard.

\section{Conclusion}

Endorphins can be attributed to the endogenous substances that the body creates an embryo to suppress the respiratory Centre. He participates in the first breath of the fetus. All other physiological factors of respiratory function after birth the fetus.

\section{References}

1. Bryn VB (2016) Normal Physiology. BI Tkachenko (Eds.). Exec and Extras. (3rd edn.)., M: GEOTAR Media, pp. 688.

2. Degtyarev vp, Sorokina ND (2016) Normal physiology. Tutorial GEOTAR Media, 480.

3. (2012) J West Physiology of respiration. Basics, Litterra, pp. 312.

4. Kamkin AG, Kiselyova Is (2013) Atlas of Physiology in two volumes. M GEOTAR media 408.

5. Kogan UA, Kruglikov G, Tseluiko ss (2013) Respiratory pathology Atlas, VS Paukov (Eds.), Publishing Litterra pp. 530.

6. Kuselman AI (2006) Function of endorphins, excess and deficiency of the hormone/methodical recommendations. M GEOTAR Media pp. 288.

7. Pokrovsky VM, Abushkevich VG, Potjagajlo EG, Pohodko AG (2003) Cardio respiratory Synchronism: identifying a person, dependent on the properties of the nervous system and the functional State of the organism. Advances in physiological Sciences 34(3): 68-77.

8. Sergius MS (1950) Respiratory center of mammals. M pp. 514.

9. Telae LZ, Aghajanian NA (2015) Normal physiology. Tutorial M Litterra pp. 768.

10. Mazurin AV, Vorontsov IM(1985) Propedeutics of childhood diseases. M Medicine pp. 646.
ISSN: 2574-1241

DOI: 10.26717/BJSTR.2019.18.003220

Shaposhnikov Veniamin Ivanovich. Biomed J Sci \& Tech Res

This work is licensed under Creative Commons Attribution 4.0 License

Submission Link: https://biomedres.us/submit-manuscript.php

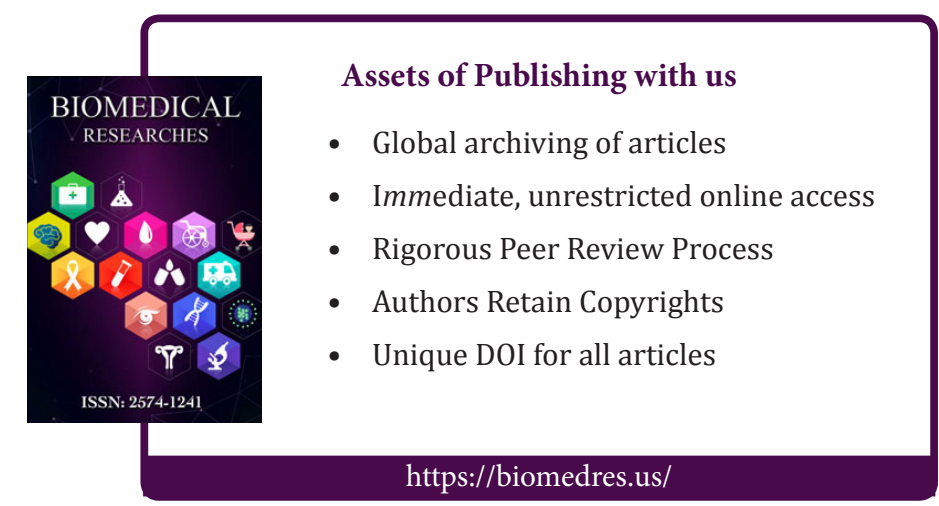

